\title{
Termite resistance of DMDHEU-treated wood
}

\author{
H. Militz $\cdot$ S. Schaffert $\cdot$ B. C. Peters $\cdot$ C. J. Fitzgerald
}

Received: 23 February 2009/Published online: 11 June 2010

(C) The Author(s) 2010. This article is published with open access at Springerlink.com

\begin{abstract}
Four field trials were conducted with wood modified with dimethyloldihydroxy-ethyleneurea (DMDHEU) in contact with subterranean termites. Trials 1 to 3 were conducted with Coptotermes acinaciformis (Froggatt); 1 and 2 in southeast Queensland, and 3 in northern Queensland, Australia. Trial 4 was conducted in northern Queensland with Mastotermes darwiniensis (Froggatt). Four timber species (Scots pine, beech, Slash pine and Spotted gum) and two levels (1.3 M and 2.3 M) of DMDHEU were used. The tests were validated. DMDHEU successfully prevented damage by $C$. acinaciformis in south-east Queensland, but not in northern Queensland. It also did not protect the wood against $M$. darwiniensis. Except for beech in trial 4, DMDHEU led to reduced mass losses caused by termite attack compared to the unmodified feeder stakes. Slash pine (in trials 1 and 3) and Spotted gum (in trial 1) presented low mass losses. Modification of Scots pine was more effective against termite damage than the modification of beech.
\end{abstract}

\section{Introduction}

Recently, researchers worldwide have tried to develop new technologies to modify wood to improve some of its properties, such as low-dimensional stability, UV/ sunlight degradation and biological durability. A comprehensive overview of

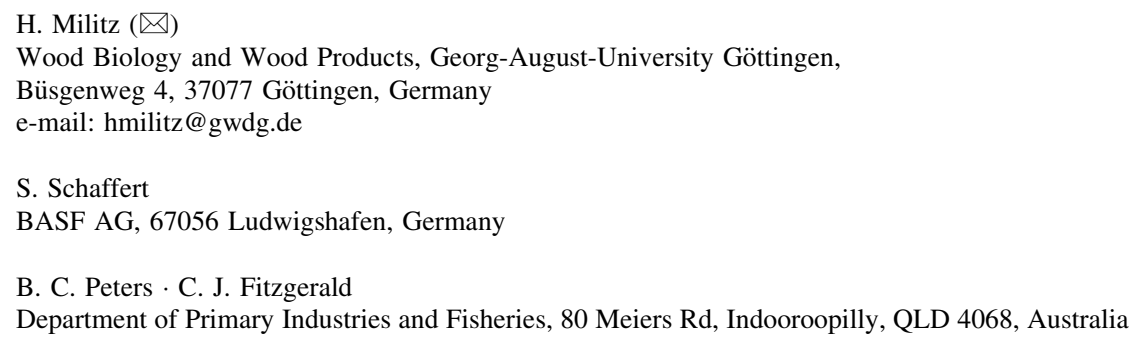


existing techniques is given by Hill (2006). One of the promising techniques involves the use of N-methylol-based agents (Nicholas and Williams 1987; Militz 1993).

$\mathrm{N}$-methylol compounds are widely used in the textile industry to improve cotton or other cellulose-based fabrics. They enhance wash-and-wear properties and help fix colour or other agents to fibres. Dimethyloldihydroxy-ethyleneurea (DMDHEU) and low-formaldehyde-containing derivatives are the most widely used N-methylol compound in the textile industry.

Chemical wood modification with DMDHEU or its derivatives are applicable to both solid lumber and wood-based composites. The mode of action is based on DMDHEU cross-linking with wood compounds and its self-polycondensation within the cell wall. Technically, the modified material is a wood-polymer composite with the appearance and texture of solid wood.

One of the main advantages of DMDHEU-based modification is an increase in dimensional stability. Impregnation causes permanent bulking of the cell wall and thus reduces subsequent dimensional changes of the wood. Tests with DMEU (dimethylolethyleneurea) and DMDHEU resulted in anti-shrink efficiencies (ASE) of up to $70 \%$ (Militz 1993; Krause et al. 2008). In addition, high durability against white, brown and soft rot fungi was obtained, but the mode of action against basidiomycetes is not fully understood. Furthermore, at higher chemical loadings, the hardness of the wood is considerably increased. Due to the durability improvement against fungi, in combination with hardness improvement, a certain resistance against termite damage could be possible. However, only limited knowledge on the resistance of DMDHEU-treated wood against termites exists. Yusuf et al. (1995) and Schaffert et al. (2006) showed that a certain improvement can be reached.

Various N-methylol compounds have been developed by the textile industry in the past 40 years, but only DMDHEU and its derivatives were widely accepted. The reactive functional groups in the molecule are the two N-methylol groups (Fig. 1a).

To reduce formaldehyde emissions from DMDHEU, the molecule is also partially methylolated to mDMDHEU (Fig. 1b). However, the reactivity of methylolated DMDHEU is lower than that of DMDHEU. Various catalysts are used to enhance the reactivity of cross-linking agents (Krause et al. 2008). One of the best catalysts was magnesium chloride $\left(\mathrm{MgCl}_{2}\right)$, which was used in the reported results below. Recently, the process has been developed to a practical scale by joint research efforts of BASF and the University Göttingen and got the brand name "Belmadur".

a<smiles>O=C1N(CO)C(O)C(O)N1CO</smiles>

b

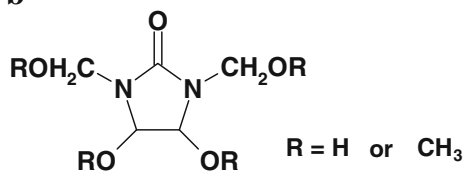

Fig. 1 a DMDHEU (dimethyloldihydroxy-ethyleneurea). b modified (methylolated) DMDHEU 
Four field trials were conducted against subterranean termites with DMDHEUtreated wood and are reported in this paper. Trials 1-3 were conducted against Coptotermes acinaciformis (Froggatt): trials 1 and 2 in south-east Queensland and trial 3 in northern Queensland, Australia. One trial (Trial 4) was conducted against Mastotermes darwiniensis (Froggatt) in northern Queensland.

\section{Materials and methods}

\section{Experimental specimens}

Two treatment levels were applied to four timber species:

- level A: 1.3 M treatment concentration DMDHEU; and level B: 2.1 M treatment concentration DMDHEU. From earlier trials, it is known that with a treatment with 1.3 M concentration, a weight per cent gain (WPG) of the wood samples of approx. $15-20 \%$ is reached, with $2.1 \mathrm{M}$, a WPG of $25-30 \%$.

- Scots pine (sapwood): Pinus sylvestris from Germany in trials 1-4. The average liquid uptake was $550 \mathrm{~kg} / \mathrm{m}^{3}$. The wood was nearly free of heartwood; however, small bands of heartwood could appear.

- Beech: Fagus sylvatica from Germany in trials 1-4; average liquid uptake $660 \mathrm{~kg} / \mathrm{m}^{3}$.

- Slash pine (pure sapwood): Pinus elliottii from Queensland, Australia in trials 1 and 3 ; average liquid uptake $485 \mathrm{~kg} / \mathrm{m}^{3}$.

- Spotted gum: Corymbia maculata from Queensland, Australia in trial 1; average liquid uptake $250 \mathrm{~kg} / \mathrm{m}^{3}$.

The material was kiln dried before treatments and conditioned to approx. $12 \%$ m.c. The wood was impregnated with an aqueous treatment solution in a vacuum/ pressure process (100 mbar for $1 \mathrm{~h}, 12$ bar for $3 \mathrm{~h}$ ) and subsequently dried and cured at approx. $130^{\circ} \mathrm{C}$ for $48 \mathrm{~h}$. The liquid uptake figures are pointing to a nearly full impregnation of both pine wood species and beech, whereas Spotted gum proved to be refractory. After the treatment, the samples were conditioned for 6 weeks prior to sampling. In the case of Scots pine and beech, larger sample sizes were treated $\left(115 \times 30 \times 1200 \mathrm{~mm}^{3}\right)$, and the final sample sizes were produced out of these. In case of Slash pine and Spotted gum, the final sample sizes as used in the trials were treated. By this procedure, even Spotted gum with low liquid uptakes will have had a protected outer zone. In order to determine intensity and homogeneity of the modification process, the content of DMDHEU in modified beech and pine sapwood wood was measured indirectly via determination of the nitrogen content. Natural wood contains negligible amounts of nitrogen, whereas $16 \%$ of the molecular weight of DMDHEU is represented by nitrogen, leading to a direct correlation between nitrogen content of the modified timber and the amount and distribution of the modification agent. Determination of nitrogen content was carried out by elementary analysis according to European Standard DIN EN 13654-2 (2001). The analysis showed that in beech and pine species, an even distribution of nitrogen was given, whereas in Spotted gum, only a shallow border of nitrogen 
exists on the outer parts of the samples, with a somewhat deeper penetration in end grain direction (Table 1).

Termites

Coptotermes acinaciformis is the most economically important termite in Australia (Gay and Calaby 1970). Trial 1 was conducted with the tree-nesting form on private property near Esk $\left(27^{\circ} 17^{\prime} \mathrm{S}, 152^{\circ} 20^{\prime} \mathrm{E}\right), 45 \mathrm{~km}$ north-west of Brisbane, Queensland. Test specimens were exposed to feeding by $C$. acinaciformis using a brick assembly method (Australasian Wood Preservation Committee 2007). Trial 2 was also conducted with the tree-nesting form on DPI\&F property at Indooroopilly $\left(27^{\circ} 30^{\prime} \mathrm{S}\right.$, $\left.152^{\circ} 59^{\prime} \mathrm{E}\right)$, Queensland. Test specimens were exposed to feeding by C. acinaciformis using a novel rubbish-bin method adapted from Grace et al. (1992). Coptotermes acinaciformis occurs in mounds (epigeous nests) in regions north of the Tropic of Capricorn. It occurs on private property near Hervey Range $\left(19^{\circ} 21^{\prime} \mathrm{S}\right.$, $146^{\circ} 29^{\prime} \mathrm{E}$ ), about $35 \mathrm{~km}$ west of Townsville in tropical north Queensland, where Trial 3 was conducted. Mastotermes darwiniensis is by far the most destructive termite in Australia (Gay and Calaby 1970). Trial 4 was conducted on private property at Rowes Bay, Townsville $\left(19^{\circ} 13^{\prime} \mathrm{S} ., 146^{\circ} 47^{\prime} \mathrm{E}\right.$.), northern Queensland.

Field assay

\section{Trial 1}

Test specimens were exposed in 6-1 plastic test containers (lunch boxes: Bipa Plastics, Item No. 3314, Australia, for set-up of trials see Fig. 2). Sixteen test containers were used, representing eight replicates of each treatment. Test specimens $\left(25 \times 70 \times 150\right.$ or $\left.190 \mathrm{~mm}^{3}\right)$ were randomly arranged and alternated with highly susceptible feeder specimens (Scots pine, $35 \times 70 \times 190 \mathrm{~mm}^{3}$ ). Test specimens (4) and feeder specimens (4) were horizontally oriented (side-by-side) and separated by corrugated cardboard. All containers were placed on hollow masonry bricks (100 mm thick). The bricks were on a timber-filled trench, which was known to contain an infestation of $C$. acinaciformis. Wooden pegs $(200 \mathrm{~mm}$ long) aided termite access through the bricks and into the containers. Each container was covered with insulating material and secured with soil. Following exposure for 47 weeks (Australasian Wood Preservation Committee 2007), the specimens were inspected and assessed for termite damage using a visual rating system and mass loss. The presence of heartwood in coniferous specimens, after exposure to termites,

Table 1 Nitrogen content $( \pm \mathrm{SD})$ for specimens with two modification levels

\begin{tabular}{lll}
\hline Modification level & \multicolumn{2}{l}{ Test specimens } \\
\cline { 2 - 3 } & Scots pine & Beech \\
\hline A & $2.79 \pm 0.7$ & $2.40 \pm 0.24$ \\
B & $3.16 \pm 1.03$ & $3.42 \pm 0.31$ \\
\hline
\end{tabular}



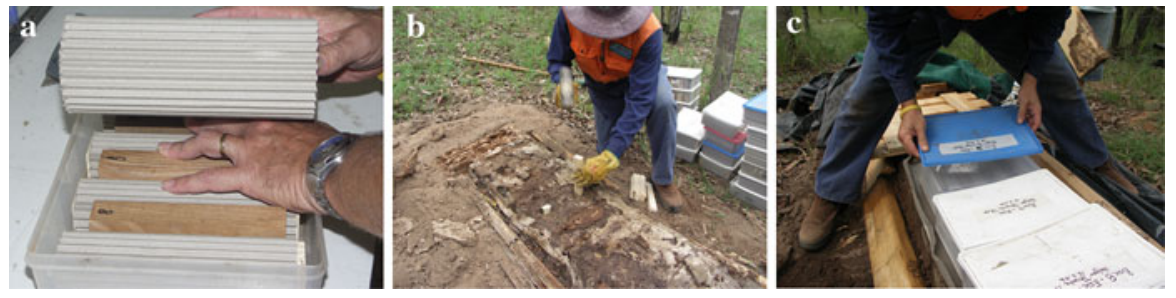

Fig. 2 Termite field trails: a placing treated samples beside untreated controls in lunch boxes, wrapped in corrugated card board, b preparing field with sticks, c placing bottom-opened lunch boxes on the prepared field, afterwards covering with sheds and soil

was investigated using chemical tests (Australian/New Zealand Standard AS/NZS 1605 2000).

\section{Trial 2}

Test specimens were exposed in two 240-1 plastic rubbish bins (wheelie bins: Otto Plastics, Australia). Test specimens $\left(25 \times 75 \times 125 \mathrm{~mm}^{3}\right)$ were randomly arranged and alternated with susceptible feeder specimens (Scots pine: $15 \times 70 \times$ $150 \mathrm{~mm}^{3}$ ). Test specimens (4) and feeder specimens (4) were vertically oriented (side-by-side), separated by corrugated cardboard and secured with tape to form bundles (replicates). Four bundles were placed in each of two rubbish bins and surrounded with timber. The rubbish bins had been half-filled with timber offcuts and connected to timber in the soil through a 100-mm-diameter hole in the bottom of each bin. The bins were known to contain infestations of $C$. acinaciformis. Following exposure for 52 weeks, the specimens were inspected and assessed for termite damage, as in trial 1.

\section{Trial 3}

The four test containers were attached to a $C$. acinaciformis mound, via hollow concrete bricks established adjacent to one another along a section of a trench, according to the method described by Peters et al. (2008). Following exposure for 36 weeks, the specimens were inspected and assessed for termite damage, as in trial 1.

\section{Trial 4}

Four test specimens (each $25 \times 70 \times 190 \mathrm{~mm}^{3}$ ) and feeder specimens (Scots pine, $35 \times 70 \times 190 \mathrm{~mm}^{3}$ ) were horizontally oriented (side-by-side) and separated by corrugated cardboard in a test container, as in trial 1 . Six test containers were used and placed on hollow masonry bricks. The bricks were on a timber-filled trench, which was known to contain an infestation of $M$. darwiniensis. Following exposure for 36 weeks, the specimens were inspected and assessed for termite damage, as in trial 1. 
Experimental design

\section{Trial 1}

Four timber species (Scots pine, beech, Slash pine and Spotted gum) were used, with two levels of DMDHEU within each timber species and eight replicates. The mean oven dry mass for the test specimens was as follows: Scots pine, $194.3 \mathrm{~g}$ (standard error $(\mathrm{SE})=5.8$, number of test specimens $(N)=16$ ); beech, $255.8 \mathrm{~g}$ $(\mathrm{SE}=3.0, N=16)$; Slash pine, $197.4 \mathrm{~g}(\mathrm{SE}=3.5, N=16)$; and Spotted gum, $234.2 \mathrm{~g}(\mathrm{SE}=3.1, N=16)$. The mean oven dry mass for the Scots pine feeder specimens was $186.0 \mathrm{~g}(\mathrm{SE}=2.4, N=64)$.

\section{Trial 2}

Two timber species (Scots pine and beech) were used, with two levels of DMDHEU within each timber species and eight replicates. The mean oven dry mass for the test specimens was as follows: Scots pine, $133.5 \mathrm{~g}(\mathrm{SE}=3.2, N=16)$ and beech, $158.5 \mathrm{~g}(\mathrm{SE}=1.5, N=16)$. The mean oven dry mass for the Scots pine feeder specimens was $66.6 \mathrm{~g}(\mathrm{SE}=1.4, N=32)$.

\section{Trial 3}

Three timber species (Scots pine, beech and Slash pine) were used, with two levels of DMDHEU within each timber species and two replicates. Four other test specimens were used to balance the design, but are not reported here. The mean oven dry mass for the test specimens was as follows: Scots pine, 211.0 g ( $\mathrm{SE}=3.3$, $N=4)$, beech, $240.3 \mathrm{~g}(\mathrm{SE}=3.2, N=4)$ and Slash pine, 179.4 (SE = 10.3, $N=4)$. The mean oven dry mass for the Scots pine feeder specimens was $203.8 \mathrm{~g}$ $(\mathrm{SE}=4.8, N=16)$.

\section{Trial 4}

Two timber species (Scots pine and beech) were used, with two levels of DMDHEU within each timber species and six replicates. The mean oven dry mass for the test specimens was as follows: Scots pine, $192.9 \mathrm{~g}(\mathrm{SE}=5.1, N=12)$ and beech, $259.6 \mathrm{~g}(\mathrm{SE}=5.0, N=12)$. The mean oven dry mass for the Scots pine feeder specimens was $191.5 \mathrm{~g}(\mathrm{SE}=3.7, N=24)$.

\section{Statistical analyses}

Analysis of the visual rating and percentage mass loss data of test specimens using Kruskal-Wallis non-parametric analysis of variance (ANOVA) to partition the variance due to timber species, DMDHEU levels within timber species and replicates was conducted using StatSoft, Inc. (2006). Analyses (see Table 2) were done regarding the columns, not the rows. Means followed by the same letter within each trial are significantly different at $5 \%$. 
Table 2 Mean percentage mass loss ( \pm SE standard error) for specimens in four trials

\begin{tabular}{llccll}
\hline Trial & $\begin{array}{l}\text { Feeder specimens } \\
\text { (unmodified) }\end{array}$ & \multicolumn{4}{l}{ Test specimens (modified with DMDHEU) } \\
\cline { 3 - 6 } & Scots pine & Beech & Slash pine & Spotted gum \\
\hline 1 & $62.3 \pm 2.9$ & $2.2 \mathrm{a} \pm 1.2$ & $7.1 \mathrm{a} \pm 2.8$ & $1.0 \mathrm{a} \pm 0.7$ & $0.5 \mathrm{a} \pm 0.3$ \\
2 & $68.0 \pm 4.5$ & $0.7 \mathrm{~b} \pm 0.4$ & $2.9 \mathrm{a} \pm 1.0$ & N/A & N/A \\
3 & $70.5 \pm 6.4$ & $10.3 \mathrm{a} \pm 4.7$ & $34.7 \mathrm{a} \pm 16.3$ & $4.0 \mathrm{a} \pm 1.5$ & N/A \\
4 & $76.1 \pm 2.8$ & $11.6 \mathrm{~b} \pm 3.9$ & $100.0 \mathrm{a} \pm 0.0$ & N/A & N/A \\
\hline
\end{tabular}

Means not followed by the same letter are significantly different at $5 \%$

N/A not applicable

\section{Results}

\section{Trial 1}

Termites entered all test containers but had departed by harvest. Mass losses in the Scots pine feeder specimens averaged $62.3 \%$ ( $\mathrm{SE}=2.9$; range $21.9-100 \%$ ): nonsusceptible heartwood was implicated (by chemical analysis) in the timber remaining. Accordingly, termite feeding pressure was considered adequate for a valid trial.

DMDHEU was successful in limiting mass loss due to $C$. acinaciformis feeding to an average of $2.7 \%$ [up to $5 \%$ mass loss is acceptable (Australasian Wood Preservation Committee 2007)]. However, the treatments were more successful on Scots pine, Slash pine and Spotted gum than on beech. The statistical analysis indicated that the effect of timber species, DMDHEU levels within timber species and replicates was not significant. Mean percentage mass loss was $2.7 \%$ ( $\mathrm{SE}=0.8$, $N=64$ ): nine of the 64 test specimens had a percentage mass loss in excess of $5 \%$.

\section{Trial 2}

Termites entered all test bundles and were present at harvest. Mass losses in the Scots pine feeder specimens averaged $68.0 \%$ ( $\mathrm{SE}=4.5$; range $1.1 \%-98.4 \%$ ). Accordingly, termite feeding pressure was considered adequate for a valid trial (Fig. 3).

DMDHEU was successful in limiting mass loss due to $C$. acinaciformis feeding to an average of $1.8 \%$ : results were slightly better with the treated Scots pine than with the beech. Analysis of the visual rating and percentage mass loss data indicated that the effect of timber species was marginally significant $(P=0.04)$, but other variables were not significant. Mean percentage mass loss was $1.8 \%$ ( $\mathrm{SE}=0.56$, $N=32$ ). Five of the 32 test specimens had a percentage mass loss in excess of $5 \%$.

\section{Trial 3}

Termites entered all test containers but had departed by harvest. Mass losses in the Scots pine feeder specimens averaged 70.5\% ( $\mathrm{SE}=6.4$; range $22.2-100 \%$ ): non- 
Fig. 3 Mean percentage mass loss (standard error \pm SE) for specimens in four trials

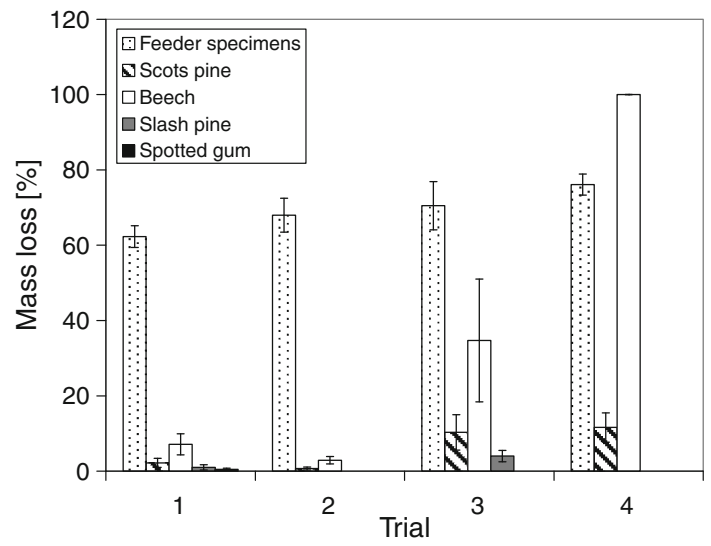

susceptible heartwood was implicated (by chemical analysis) in the timber remaining. Accordingly, termite feeding pressure was considered adequate for a valid trial (Fig. 3).

DMDHEU improved the performance; however, it was not successful in limiting mass loss due to C. acinaciformis feeding to less than 5\%. Only Slash pine (4\% mass loss) seemed to be protected well. Analysis of the visual rating and percentage mass loss data indicated that the effect of none of the mentioned variables was significant. Mean percentage mass loss was $16.4 \%(\mathrm{SE}=6.5, N=12)$ : seven of the 12 test specimens had a percentage mass loss in excess of $5 \%$.

\section{Trial 4}

Termites entered all test containers but had departed by harvest. Mass losses in the Scots pine feeder specimens averaged 76.1\% (SE $=2.8$; range 47.0-97.8\%): nonsusceptible heartwood was implicated (by chemical analysis) in the timber remaining. Accordingly, termite feeding pressure was considered adequate for a valid trial (Fig. 3).

With the test specimens, only DMDHEU-treated Scots pine remained; the treated beech had been completely destroyed, with nothing remaining. Mean mass loss for the DMDHEU-treated Scots pine was 11.6\% ( $\mathrm{SE}=3.9, N=12)$. DMDHEU improved the performance of Scots pine; however, it was not successful in limiting mass loss due to $M$. darwiniensis feeding to less than 5\%. Differences between the two levels of DMDHEU-treated Scots pine were not significant.

\section{Intensity and homogeneity of DMDHEU modification}

Nitrogen content as a direct indicator for the intensity of the modification was very much comparable for modified beech and pine wood. However, a higher standard deviation for pine compared to beech at both levels is obvious (Table 1). 


\section{Discussion}

Earlier trials showed an improved resistance of DMDHEU-treated wood against Coptotermes formosanus and Reticulitermes speratus in a laboratory choice test (Yusuf et al. 1995) and in a Portuguese field trial (Schaffert et al. 2006). However, due to known differences in the biological behaviour, it was of interest to get information on the termite resistance of some European-grown and Australia-grown wood species under Australian field conditions.

The trials of this study were conducted during particularly dry weather in 2007/ 08. Much of southern and eastern Australia has experienced widespread drought during the past 6 years (Australian Bureau of Meteorology 2007). Lenz et al. (1992) noted that environmental factors, particularly soil moisture and temperature, greatly influence the level of termite foraging in the upper layers of the soil. Furthermore, even when termites have contacted the test specimens and the adjacent supply of feeder wood is providing a suitable feeding site, the termites may abandon the site and retreat deeper into the ground once the top layers of soil dry out or become too wet or too warm. It is likely that termites were not foraging strongly in the test containers for much of the duration of the trials. Accordingly, the exposure periods were considerably longer than would be required under nondrought conditions.

Nevertheless, termite feeding was adequate for four valid trials. Of interest was the resistance of Scots pine heartwood in feeder specimens to both $C$. acinaciformis and $M$. darwiniensis. The heartwood of several other Pinus spp. has similarly been reported as resistant to these termites (Peters and Fitzgerald 2004). Care should be taken to select only Pinus sp. sapwood when preparing test specimens with woodpreservative formulations for trials against termites: spot-testing for heartwood content, using the method of Australian/New Zealand Standard AS/NZS 1605 (2000), is recommended.

There was good accord between the results from the visual rating system (AWPA 2007) and the mass losses in the test specimens. Negative mass losses can result from a combination of variation in estimating initial moisture content of the specimens and sorption during field exposure. Creffield (1994) conditioned test specimens in a constant temperature room held at $32^{\circ} \mathrm{C}$ and $75 \%$ relative humidity for 3 weeks. After conditioning, test specimens were weighed to determine their initial mass. Spare, unexposed specimens were designated as conditioning controls and used to adjust losses of mass in test specimens exposed to termites. Gains in mass for highly resistant specimens were reported (Creffield 1994), and a qualitative scoring system (based on visible wood consumption) was proposed, according to the method of Beesley (1978). For preservative-treated test specimens, drying in a vacuum oven at $40^{\circ} \mathrm{C}$ and $-95 \mathrm{kPa}$ for five days to remove any residual solvents and volatiles prior to weighing is recommended (Australasian Wood Preservation Committee 2007). Peters and Allen (1995) demonstrated enhanced termite feeding on wood that had been oven dried at $105^{\circ} \mathrm{C}$ for $24 \mathrm{~h}$. Where quantitative mass losses are to be used, care and precision in determining initial moisture content of the test specimens is important, especially where 5\% mass loss is the criterion between "pass/fail". 
With respect to the performance of DMDHEU in Scots pine sapwood and in beech against $C$. acinaciformis, the results from the trial at Esk were comparable with the results from the rubbish-bin trial at Indooroopilly. There did, however, appear to be a slightly greater termite resistance in the modified Scots pine sapwood compared to modified beech. This observation was supported in Townsville where M. darwiniensis completely devoured the treated beech, but the treated Scots pine had some termite resistance. This species-depending difference was quite unexpected, because carbon/nitrogen $(\mathrm{C} / \mathrm{N})$ analyses demonstrated a comparable uptake of DMDHEU in the modified beech and the modified pine samples. Furthermore, standard deviation of nitrogen content was higher for Scots pine compared to beech which makes the explanation of the differences between modified pine and beech even more difficult. Further work with DMDHEUmodified wood is recommended. From wood preservatives, it is known that certain amounts of biocides can leach out and disturb during practical trials. Krause (2006) and Wepner (2006) measured fixation rates of DMDHEU and proved very low leaching rates. These compounds are furthermore not biocidal and will not have influenced the field tests.

\section{Conclusion}

From these results, it is concluded that the termite-feeding pressure was adequate for four valid trials. The DMDHEU passed the test against $C$. acinaciformis in south-east Queensland, but not in northern Queensland; however, mass loss caused by termite attack was clearly reduced compared to the unmodified feeder stakes. The DMDHEU did not pass the test against $M$. darwiniensis; again mass loss was reduced compared to the unmodified references. A concentration effect was not detectable. The two levels of DMDHEU appeared comparable. The modification of Scots pine sapwood appeared more effective against termite attack than modification of beech. This was not expected because of comparable DMDHEU loadings in both species. Scots pine heartwood was resistant to both termite species.

Open Access This article is distributed under the terms of the Creative Commons Attribution Noncommercial License which permits any noncommercial use, distribution, and reproduction in any medium, provided the original author(s) and source are credited.

\section{References}

American Wood-Preservers' Association (2007) E21-06: standard test method for the evaluation of preservative treatments for lumber and timbers against subterranean termites in above-ground, protected applications (UC1 and UC2). In: Book of standards. pp 365-369. AWPA, Birmingham, Alabama, USA

Australasian Wood Preservation Committee (2007) Protocols for assessment of wood preservatives. AWPC Publication, Melbourne, 30 pp. <http://www.tpaa.com.au/files/AWPC\%20protocols.pdf (accessed 07/03/08) 
Australian Bureau of Meteorology (2007) Special climate statement 14: six years of widespread drought in southern and eastern Australia November 2001-October 2007. Bureau of Meteorology, Melbourne, 6 pp. http://www.bom.gov.au/climate/current/statements/scs14.pdf (accessed 07/03/08)

Australian/New Zealand Standard AS/NZS 1605 (2000) Methods for sampling and analysing timber preservatives and preservative-treated timber. Standards Australia and Standards New Zealand, Homebush, Australia. $80 \mathrm{pp}$

Beesley J (1978) An Australian test of wood preservatives. Part I. Preservatives, principles and practices. Mater Organ 13:31-50

Creffield JW (1994) A field method for determining the above-ground resistance of wood and wood products to attack by subterranean termites. Paper presented to the International Research Group (Stockholm) on Wood Preservation, 25th Annual Meeting, Bali, Indonesia, Doc. No. IRG/WP 9420035. $15 \mathrm{pp}$

European Standard DIN EN 13654-2 (2001) Bodenverbesserungsmittel und Kultursubstrate-Bestimmung von Stickstoff-Teil 2: Verfahren nach Dumas. Deutsche Fassung EN 13654-2

Gay FJ, Calaby JH (1970) Termites of the Australian region. In: Krishna K, Weesner FM (eds) Biology of termites, vol 2. Academic Press, New York, pp 393-448

Grace JK, Yamamoto RT, Tamashiro M (1992) Resistance of borate-treated Douglas-fir to the Formosan subterranean termite. Forest Prod J 42(2):61-65

Hill C (2006) Wood modification. Wiley Series in Renewable Resources. ISBN-100-470-02172-1

Krause A (2006) Holzmodifizierung mit N-Methylolvernetzern. Dissertation Universität Göttingen, Sierke Verlag. $229 \mathrm{pp}$

Krause A, Wepner F, Xie Y, Militz H (2008) Wood protection with DMDHEU and its derivatives. In: Development of commercial wood preservatives. Edited by Schultz, Militz, Freeman, Goodell, Nicholas, ACS Symposium Series 982

Lenz M, Creffield JW, Barrett RA (1992) An improved field method for assessing the resistance of woody and non-woody materials to attack by subterranean termites. Mater Organ 27:89-115

Militz H (1993) Treatment of timber with water soluble dimethylol resins to improve their dimensional stability and durability. Wood Sci Technol 27:347-355

Nicholas D, Williams A (1987) Dimensional stabilisation of wood with dimethylol compounds. Paper presented to the International Research Group (Stockholm) on Wood Protection, 18th Annual Meeting, Honey Harbour, Ontario, Canada, Doc. No. IRG/WP 3412. 8 pp

Peters BC, Allen PJ (1995) Susceptibility of conditioned softwood baits to Coptotermes spp. (Isoptera: Rhinotermitidae). Mater Organ 29(1):47-65

Peters BC, Fitzgerald CJ (2004) Field exposure of Pinus heartwoods to subterranean termite damage (Isoptera: Rhinotermitidae, Mastotermitidae). Aus Forest 67(2):75-81

Peters BC, Lenz M, Creffield JW (2008) Field assessment of the resistance of timber products to termite (Isoptera) damage: results can change with the amount of bait wood. Sociobiology 51(2):425-435

Schaffert S, Nunes L, Krause A, Militz H (2006) Resistance of DMDHEU treated pine wood against termite and fungi attack in field testing according to EN 252. Results after 30 months. Paper presented to the International Research Group (Stockholm) on Wood Protection, 37th Annual Meeting, Troms $\emptyset$, Norway, Doc. No. IRG/WP 06-40354. 10 pp

StatSoft Inc (2006) STATISTICA for Windows [Computer program manual]. Tulsa, USA

Wepner F (2006) Entwicklung eines Modifizierungsverfahrens für Buchenfurniere auf Basis von zyklischen N-Methylolverbindungen. Sierke Verlag $258 \mathrm{pp}$

Yusuf S, Imamura Y, Takahashi M, Minato K (1995) Biological resistance of wood chemically modified with non-formaldehyde cross-linking agents. Mokuzai Gakkaishi 41(2):163-169 